\title{
IMPLEMENTATION OF DISCOVERY LEARNING MODEL TO IMPROVE MATHEMATICS LEARNING OUTCOMES STUDENTS IN CLASS VII A MTs NEGERI 2 BENGKALIS
}

\section{PENERAPAN MODEL PEMBELAJARAN DISCOVERY LEARNING UNTUK MENINGKATKAN HASIL BELAJAR MATEMATIKA SISWA KELAS VII A MTS NEGERI 2 BENGKALIS}

\author{
Osman $^{1)}$, Rodiah $^{2)}$ \\ ${ }^{1)}$ MTs Negeri 2 Bengkalis \\ ${ }^{2)}$ SMA Negeri 1 Bengkalis \\ Email : h.osmans@yahoo.co.id
}

Submitted: (23 April 2020); Accepted: (29 Mei 2020);

Published: (31 Mei 2020)

\begin{abstract}
This research aims to increase the learning outcomes of students and the activity of students and teacher by applying Discovery Learning Model. The classroom action research conducted using two cycles. Each cycle consists of 2 meetings. This study also equipped with teacher activities and student activities, which are assessed using observation sheets while teaching and learning activities take place in class. Activities of students and teacher assessed by the observer. The results obtained, in test I, in the first cycle, $72 \%$ of students have achieved completeness, and fall into enough category. While in test 2, in the second cycle, $92 \%$ of students have achieved completeness, and fall into the very good predicate. The average learning activieties of students from the first cycle is $74 \%$ with enough category and the second cycle with an average of $96 \%$ is in the very good category. The average activities of teacher from the first cycle was 77,6\% with a good category and the second cycle with an average of 97,5\% is in the very good category. Based on the results of the research, it could be concluded that the implementation of the Discovery Learning Model can improve the activity and learning result of students of class VII A MTs Negeri 2 Bengkalis.
\end{abstract}

Keywords : Classroom action research, Discovery learning model, Students' activities, Learning outcomes

\section{PENDAHULUAN}

Proses interaksi antara siswa, guru dan sumber belajar pada suatu lingkungan belajar disebur dengan proses belajar dan mengajar, atau lebih dikenal dengan istilah proses pembelajaran. Bagian terpenting dalam pembelajaran menurut Subanji (2013) adalah bagaimana siswa bisa memahami dan mengerti informasi yang disampaikan oleh guru. Karena tujuan utama diselenggarakannya pembelajaran adalah keberhasilan siswa belajar pada suatu mata pelajaran maupun pendidikan pada umumnya (Krismanto, 2003).

Perkembangan ilmu pengetahuan dan teknologi (IPTEK) yang sangat cepat berdampak pada pembelajaran yang dilakukan guru. Sehingga diperlukan kemampuan untuk beradaptasi secata cepat. Adanya penemuan di bidang IPTEK juga membawa dampak terhadap pola pikir yang baik dan cara belajar serta media yang digunakan. Dengan adanya cara atau metode yang bervariasi dan dipadukan dengan media pembelajaran maka akan terbentuk pola pikir yang baik. Pola pikir yang baik dapat terbentuk jika pembelajaran dilakukan dengan membiasakan siswa untuk mengontruksi pengetahuannya sendiri. Karena dengan hasil kontruksi tersebut siswa memiliki skema yang dapat berkembang secara optimal. (Subanji, 2013). Perubahan hasil pola pikir dalam pembelajaran merupakan hal utama untuk menghadapi perkembangan IPTEK. Karena pola pikir berpengaruh besar terhadap kualitas hasil belajar siswa.

Terkait dengan cara mengajar konvensional dengan urutan langkah seperti: penyajian informasi, pemberian contoh-contoh soal, dan latihan-latihan menurut Maimunah (2016) hanya mendorong siswa untuk berpikir pada tataran tingkat rendah. Selain itu siswa 
cenderung menghindari proses belajar mengajar, karena belajar menjadi terasa sangat membosankan dan monoton.

Berdasarkan penjelasan di atas menurut Herman Hudoyo (2005) bahwa matematika merupakan ide-ide abstrak yang diberi simbolsimbol, tersusun secara hierarkis dan penalaran secara deduksi. Sehingga belajar matematika itu merupakan kegiatan mental yang tinggi. Tujuan pembelajaran matematika yang dinyatakan dalam departemen pendidikan nasional tahun 2006 adalah (1) agar siswa memahami konsep matematika, menjelaskan keterkaitan antar konsep, mengaplikasikan konsep secara luwes, akurat, efisien, dan tepat, (2) menggunakan penalaran pada pola dan sifat, melakukan manipulasi matematika dalam membuat generalisasi, menyusun bukti, atau menjelaskan gagasan dan pernyataan matematika, (3) memecahkan masalah yang meliputi kemampuan memahami masalah, merancang model matematika, menyelesaikan model dan menafsirkan solusi yang diperoleh, serta (4) mengomunikasikan gagasan masalah .

Tercapainya tujuan tersebut sangat ditentukan oleh proses pembelajaran yang di dalamnya terdapat siswa, guru atau pengajar, sarana dan prasarana, serta model/metode yang digunakan dalam mengajar. Terlaksananya kegiatan pembelajaran tidak terlepas dari peranan guru sebagai fasilitator dalam menciptakan kondisi pembelajaran yang efektif sehingga terjadi proses pembelajaran yang menyenangkan, mengembangkan bahan pelajaran dengan baik, meningkatkan kemampuan siswa untuk mengikuti pelajaran, dan menguasai tujuan pendidikan yang harus mereka capai.

Dalam hal peran model/strategi/metode, serta dalam mencapai tujuan pembelajaran seperti tersebut di atas, maka perlu adanya usaha peningkatan kualitas pembelajaran. Oleh karena itu, untuk mencapai tujuan tersebut, setiap penyampaian mata pelajaran harus diorganisasikan dengan model pembelajaran yang tepat dan alur kegiatan pembelajaran dalam suatu model yang disebut sintak (Isrok'atun, \& Amelia, 2018). Dalam hal ini, menuntut guru untuk menggunakan model sesuai situasi atau kondisi di dalam kelas.
Berdasarkan pengamatan peneliti, dan pengalaman dalam mengajar sebagai guru matematika, di dalam proses pembelajaran diperoleh data bahwa masih banyak siswa kurang minat membaca, kurang mandiri dalam menemukan konsep-konsep dalam materi pembelajaran, kurang bertanggung jawab apabila diberikan tugas. Hal ini terlihat dari: seringnya siswa terlambat mengumpulkan tugas, nilai ulangan harian rendah, tidak termotivasi dalam belajar, siswa yang senang mencontek pekerjaan temannya, siswa senang berbicara di luar konteks pelajaran. Hal tersebut tidak terlepas dari kekurangan proses belajar mengajar, siswa dan guru. Adapun kelemahan guru dalam proses belajar mengajar itu diantaranya dalam menggunakan metode yang tidak bervariasi dan hanya berfokus menggunakan metode ceramah, kurang memberikan pertanyaan dan kurang mengembangkan kemandirian siswa yang berdampak pada rendahnya hasil belajar Matematika.

Berdasarkan Kurikulum 2013 MTs Negeri 2 Bengkalis, telah menetapkan bahwa KKM mata pelajaran Matematika 65. Ternyata dari observasi dan hasil ulangan harian matematika, siswa yang mengikuti ulangan harian hanya $40 \%$ yang mencapai nilai KKM. Melihat kondisi tersebut peneliti merasa terpanggil untuk mengadakan perbaikan dalam proses pembelajaran. Perbaikan dapat dilakukan dengan menggunakan model pembelajaran Discovery Learning.

Model pembelajaran adalah salah satu cara yang digunakan guru untuk menciptakan situasi pengajaran yang benar - benar menyenangkan. Salah satu model pengajaran adalah model Discovery Learning, dimana siswa mengorganisasi bahan yang dipelajari dengan bentuk akhir. Model Discovery Learning adalah memahami konsep, arti dan hubungan, melalui proses intuitif untuk akhirnya sampai kepada satu kesimpulan (Budiningsih, 2005). Penggunaan model pembelajaran mengubah kondisi belajar yang pasif menjadi kreatif dan mengubah pembelajaran yang teacher oriented ke student oriented.

Model Discovery Learning adalah salah satu cara penyajian bahan pelajaran dengan 
konsep menemukan, menggali materi yang sedang dipelajari, oleh peserta didik untuk melakukan serangkaian kegiatan. Kelebihan model Discovery Learning dapat merangsang siswa untuk lebih aktif, kreatif, mandiri, dan termotivasi dalam belajar.

Untuk menjamin keterlibatan aktif siswa dalam pembelajaran dan adanya rancangan agar siswa berpikir kreatif maka diperlukan suatu model pembelajaran. Berbagai model pembelajaran dapat digunakan tergantung karakteristik siswa dalam suatu kelas. Berdasarkan permasalahan yang peneliti hadapi, salah satu model pembelajaran yang dapat mengatasi masalah tersebut adalah model pembelajaran Discovery Learning. Model Discovery Learning adalah model yang mengarahkan siswa untuk memahami konsep, arti dan hubungan, melalui proses intuitif untuk akhirnya sampai kepada suatu kesimpulan, (Budiningsih, 2005). Discovery terjadi bila individu terlibat terutama dalam penggunaan proses mentalnya untuk menemukan beberapa konsep dan prinsip.

Menurut Syah (2004), sintaks model Discovery Learning terdiri dari enam fase atau langkah, yang disajikan pada Tabel 1 berikut.

Tabel 1. Sintaks Model Discovery Learning.

\begin{tabular}{ll}
\hline \multicolumn{1}{c}{ Fase } & \multicolumn{2}{c}{ Aktivitas (Kegiatan) } \\
\hline Fase-1 & Siswa dihadapkan pada \\
Stimulation & sesuatu yang menimbulkan \\
(Pemberian & tanda tanya kemudian \\
rangsangan) & dilanjutkan untuk tidak \\
& memberi generalisasi, agar \\
& timbul keinginan untuk \\
& menyelidiki sendiri, \\
& disamping itu juga, guru \\
& dapat memulaikan \\
& pembelajaran dengan cara \\
& mengajukan pertanyaan, \\
& anjuran membaca buku dan \\
& aktivits belajar yang lain.
\end{tabular}

Fase-2

Problem

Statement (Identifikasi masalah)
Setelah dilakukan stimulasi langkah selanjutnya adalah guru memberi kesempatan kepada siswa untuk mngidentifikasikan sebanyak mungkin agendaagenda masalah yang relevan dengan bahan pelajaran.

Fase-3 Data Ketika ekplorasi berlangsung Collection guru juga memberi kesempan (Pengumpulan kepada siswa untuk data) mengumpulkan imformasi sebanyak-banyaknya yang relevan untuk membuktikan benar atau tidaknya hipotesis.

Fase-4 Data Semua informasi hasil Processing bacaan, wawancara, (Pengolahan observasi, dan sebagainya. Data) Semua diolah dan diacak, diklasifikasikan, bahkan dihitung dengan cara tertentu serta ditafsirkan pada tingkat kepercayaan tertentu.

$\begin{array}{llr}\text { Fase-5 } & \text { Pada tahap ini siswa } \\ \text { Verification } & \text { melakukan } & \text { pemeriksaan } \\ \text { (Pembuktian) } & \text { kebenaran hipotesis atau } \\ & \text { jawaban } & \text { sementara } \\ & \text { dibandingkan dengan hasil } \\ & \text { terkait pengolahan data. }\end{array}$

Fase-6 Siswa diajak untuk Generalization melakukan generalisasi (Penarikan konsep yang sudah pesimpulan) dibuktikan dengan kondisi umum

Penelitian terkait penerapan model Discovery Learning telah banyak dilakukan oleh peneliti-peneliti sebelumnya. Penelitian tindakan kelas (PTK) oleh Ida Suprayanti dkk (2016) dengan menerapkan model Discovery Learning berbantuan alat peraga sederhana memperoleh peningkatan aktivitas dan hasil belajar matematika pada siswa SMP. Selain itu Dewi, Maimunah, \& Siregar (2019) yang menerapkan model Discovery Learning memperoleh hasil bahwa model Discovery Learning dapat meningkatkan kemampuan pemahaman matematis peserta didik di SMA. Selanjutnya, penelitian pengembangan perangkat yang dilakukan oleh Rani, Armis, \& Maimunah (2017) juga merujuk pada model Discovery Learning dalam mengembangkan perangkat pembelajaran, serta telah memenuhi kriteria valid dan praktis. 
Berdasarkan uraian tersebut di atas peneliti tertarik untuk melakukan penelitian tindakan keals (PTK). Penelitian ini dalam rangka untuk memperbaiki proses pembelajaran dan meningkatkan hasil belajar matematika siswa Kelas VII A MTs Negeri 2 Bengkalis Tahun Pelajaran 2019/2020.

\section{METODE}

Penelitian ini berbentuk penelitian Tindakan Kelas (PTK). Penelitian ini dilakukan oleh guru yang mengajar di kelas penelitian. Penelitian ini terdiri dari empat tahap yaitu perencanaan, pelaksanaan, pengamatan dan refleksi. Setiap tahapan penelitian tersebut diharapkan dapat memperbaiki proses pembelajaran. sehingga hasil belajar siswa dapat meningkat (Kusumah \& Dwigatama, 2008). Tahapan penelitian ini dilakukan merujuk pada Arikunto (2011) yang menyatakan bahwa secara garis besar, setiap siklus dalam penelitian tindakan kelas dilaksanakan melalui empat tahap yaitu perencanaan, pelaksanaan, pengamatan, dan refleksi. Penelitian ini dilakukan secara kolaboratif artinya peneliti sebagai guru bekerjasama dengan guru lain sebagai pengamat (observer) yang juga merupakan guru matematika di SMAN I Bengkalis.

Data yang dikumpulkan pada penelitian ini adalah data kualitatif dan data kuantitatif. Data kualitatif berupa data aktivitas siswa dan aktivitas guru selama peroses pembelajaran. Data aktivitas siswa dan guru dikumpulkan dengan mengisi lembar pengamatan, dimana kegiatan guru dan siswa diberi nilai oleh pengamat (teman sejawat). Data Kuantitatif berupa data hasil belajar siswa dengan melaksanakan ulangan harian I pada siklus I dan Ulangan Harian II pada siklus II. Data hasil tes digunakan untuk menentukan ketercapaian KKM, sedangkan skor peningkatan siswa dari siklus I ke siklus II menjadi dasar bagi penentuan keberhasilan tindakan.

Lembar pengamatan yang digunakan dalam penelitian ini.adalah lembar pengamatan terfokus. Lembar pengamatan yang berfokus berisi aspek-aspek aktivitas guru dan siswa yang menjadi pengamatan selama pembelajaran (Sukarno, 2009). Aspek-aspek yang diamati sesuai dengan fase model Discovery Learning.

Teknik pengumpulan data yang digunakan dalam penelitian ini, yaitu sebagai berikut.

\section{Teknik Observasi}

Teknik observasi dilakukan setiap kali proses belajar mengajar berlangsung, yang dilakukan oleh pengamat dengan menggunakan lembar pengamatan aktivitas guru dan siswa. Penelitian ini dilakukan pada kelas VII A semester ganjil tahun pelajaran 2019/2020.

2. Teknik Tes

Data hasil belajar siswa dikumpulkan melalui Ulangan Harian I dan Ulangan Harian II pada Materi Bilangan. Pada penelitian ini dilaksanakan 2 siklus, yaitu siklus I, terdiri dari 2 kali pertemuan dan diakhiri dengan Ulangan Harian I. Pada siklus ke II juga dilaksanakan peroses pembelajaran sebanyak 2 kali pertemuan dan diakhiri dengan Ulangan Harian II. Ulangan harian I dan II menggunakan materi dan KD yang sama, yaitu bilangan dan KD.3.1. Siswa dinyatakan tuntas atau berhasil, jika mencapai minimal nilai KKM. Perhitungan nilai siswa dengan menggunakan rumus persentase ketercapaian KKM yaitu

$P=\frac{S S}{S M} \times 100 \%$

Keterangan:

$\mathrm{P}$ : persentase ketercapaian KKM

SS : skor yang diperoleh siswa

SM : Skor maksimal

Selanjutnya menurut Suyanto (1997), tindakan dikatakan berhasil jika hasil belajar yang dicapai setelah tindakan lebih baik daripada sebelum tindakan. Dengan kata lain, tindakan dikatakan berhasil jika (1) frekuensi siswa yang mencapai KKM setelah tindakan bertambah dari sebelumnya, dan (2) adanya perbaikan aktivitas guru dan siswa dari siklus I ke siklus II.

\section{HASIL DAN PEMBAHASAN}

Hasil analisis data tentang hasil belajar siswa kelas VII A MTs Negeri 2 Bengkalis, pada siklus I dan siklus II, disajikan seperti pada Tabel 2 berikut 
Volume 2, Nomor 2, Mei 2020

DOI: https://doi.org/10.33578/prinsip.v2i2.46

jprinsip.ejournal.unri.ac.id

Tabel 2. Hasil Belajar siswa kelas VII A MTs Negeri 2 Bengkalis pada UH I dan UH II

\begin{tabular}{ccccc}
\hline & & Jumlah & \multicolumn{2}{c}{ Hasil Belajar } \\
\cline { 4 - 5 } No & UH & $\begin{array}{c}\text { Tuntas } \\
(\%)\end{array}$ & $\begin{array}{c}\text { Tidak } \\
\text { Tuntas } \\
(\%)\end{array}$ \\
\hline 1 & I & 25 & $18(72 \%)$ & 7 \\
2 & II & $(100 \%)$ & & $(28 \%)$ \\
& & $23(92 \%)$ & $2(8 \%)$ \\
\hline
\end{tabular}

Tabel 2 menunjukkan bahwa hasil belajar siswa siklus I secara individu, yaitu 18 orang siswa (72\%) mencapai ketuntasan individu dan yang tidak mencapai ketuntasan individu sebanyak 7 orang siswa (28\%). Hasill ini disebabkan antara lain: (1) siswa kurang bekerja sama dalam kegiatan kelompok, (2) siswa tidak memperhatikan penjelasan guru serta, (3) siswa tidak mau bertanya tentang materi yang belum dipahami sehingga penguasaan materi yang dipelajari menjadi kurang.

Pada siklus II hasil belajar siswa mengalami peningkatan jika dibandingkan pada siklus I. Secara individu, terdapat 23 orang siswa (92\%) mencapai ketuntasan individu dan yang tidak mencapai ketuntasan individu sebanyak 2 orang siswa (8\%). Ketuntasan individu dicapai apabila siswa mendapat nilai sesuai dengan KKM Hal ini berarti kategori peningkatan hasil belajar siswa amat baik. Terjadinya peningkatan hasil belajar siswa tidak terlepas dari aktivitas siswa dalam menemukan konsep secara berkelompok. Hal tersebut ditunjang juga oleh guru yang mempunyai peranan di dalam memberikan arahan dan dorongan agar siswa terlibat aktif selama proses pembelajaran sehingga pembelajaran menjadi berkualitas. Hal ini sejalan dengan penelitian Susanti, Maimunah, \& Siregar (2019) bahawa guru perlu memotivasi siswa agar terlibat aktif selama proses pembelajaran. Juga menurut Lazanov dalam Syaiful (2003), menunjukkan bahwa pengaruh guru sangat jelas terhadap kesuksesan belajar siswa.

Hasil observasi terhadap aktivitas siswa dengan penerapan model Discovery Learning pada siklus I dan II dapat dilihat pada Tabel 3 berikut.
Tabel 3. Hasil Pengamatan Aktivitas Siswa Untuk Siklus I dan Siklus II

\begin{tabular}{|c|c|c|c|c|c|c|c|}
\hline \multirow[t]{3}{*}{ No } & \multirow{3}{*}{$\begin{array}{l}\text { Aspek } \\
\text { Aktivitas }\end{array}$} & \multicolumn{2}{|c|}{ Siklus I } & \multirow{3}{*}{$\begin{array}{l}\text { Rata- } \\
\text { rata } \\
(\%)\end{array}$} & \multicolumn{2}{|c|}{ Siklus II } & \multirow{3}{*}{$\begin{array}{l}\text { Rata- } \\
\text { rata } \\
(\%)\end{array}$} \\
\hline & & $\mathbf{P 1}$ & $\mathbf{P 2}$ & & P1 & $\mathbf{P 2}$ & \\
\hline & & $\mathbf{N}(\%)$ & $\mathbf{N}(\%)$ & & $\mathbf{N}(\%)$ & $\mathbf{N}(\%)$ & \\
\hline 1 & $\begin{array}{l}\text { Membaca buku } \\
\text { paket }\end{array}$ & $\begin{array}{l}18 \\
(72 \%)\end{array}$ & $\begin{array}{l}21 \\
(84 \%)\end{array}$ & $78 \%$ & $\begin{array}{l}23 \\
(92 \%)\end{array}$ & $\begin{array}{l}25 \\
(100 \%)\end{array}$ & $96 \%$ \\
\hline 2 & $\begin{array}{l}\text { Keberanian } \\
\text { bertanya }\end{array}$ & $\begin{array}{l}20 \\
(80 \%)\end{array}$ & $\begin{array}{l}22 \\
(88 \%)\end{array}$ & $84 \%$ & $\begin{array}{l}23 \\
(92 \%)\end{array}$ & $\begin{array}{l}25 \\
(100 \%)\end{array}$ & $96 \%)$ \\
\hline 3 & $\begin{array}{l}\text { Menjawab } \\
\text { Pertanyaan }\end{array}$ & $\begin{array}{l}20 \\
(80 \%)\end{array}$ & $\begin{array}{l}22 \\
(88 \%)\end{array}$ & 84 & $\begin{array}{l}23 \\
(92 \%)\end{array}$ & $\begin{array}{l}24 \\
(96 \%)\end{array}$ & $94 \%$ \\
\hline 4 & $\begin{array}{l}\text { Mengerjakan } \\
\text { LAS dengan } \\
\text { baik }\end{array}$ & $\begin{array}{l}22 \\
(88 \%)\end{array}$ & $\begin{array}{l}25 \\
(100 \%)\end{array}$ & $94 \%$ & $\begin{array}{l}25 \\
(100 \%)\end{array}$ & $\begin{array}{l}25 \\
(100 \%)\end{array}$ & $100 \%$ \\
\hline 5 & $\begin{array}{l}\text { Ketepatan } \\
\text { Mengumpulkan } \\
\text { Tugas }\end{array}$ & $\begin{array}{l}17 \\
(68 \%)\end{array}$ & $\begin{array}{l}20 \\
(80 \%)\end{array}$ & $74 \%$ & $\begin{array}{l}22 \\
(88 \%)\end{array}$ & $\begin{array}{l}25 \\
(100 \%)\end{array}$ & $94 \%$ \\
\hline Rat & Rata (\%) & $78 \%$ & $88 \%$ & $73,8 \%$ & $93 \%$ & $98 \%$ & $96 \%$ \\
\hline Ket & gan & Cukup & Baik & Cukup & $\begin{array}{l}\text { Amat } \\
\text { Baik }\end{array}$ & $\begin{array}{l}\text { Amat } \\
\text { Baik }\end{array}$ & $\begin{array}{l}\text { Amat } \\
\text { Baik }\end{array}$ \\
\hline
\end{tabular}

Berdasarkan Tabel 3 dapat diketahui bahwa persentase aktivitas siswa siklus I ratarata $74 \%$ dengan kategori cukup dan siklus II rata-rata 96\% dengan kategori amat baik. Hal tersebut menunjukkan adanya perbaikan proses pembelajaran dari pertemuan 1 (P1) ke pertemuan 2 (P2). Aktivitas siswa pada kegiatan membaca buku paket, keberanian bertanya, menjawab pertanyaan, mengerjakan LAS, dan kemampuan mengumpulkan tugas pada siklus I menngkat dari cukup ke baik dan pada siklus II dari amat baik tetap amat baik. Hal ini menunjukkan bahwa model Discovery Learning yang ditunjang dengan perangkat pembelajaran yang baik seperti LAS, dapat meningkatkan aktivitas siswa selama proses pembelajaran. Sanjaya (2003) menyatakan bahwa LAS dapat membangkitkan keberanian siswa untuk bertanya, percaya diri, siswa sangat aktif dan bersemangat.

Hasil observasi aktivitas guru selama proses pembelajaran berlangsung pada siklus I dan siklus II setelah penerapan model Discovery Learning di kelas VII A MTs Negeri 2 Bengkalis tahun pelajaran 2019/2020 dapat dilihat pada Tabel 4 berikut. 
Volume 2, Nomor 2, Mei 2020

DOI: https://doi.org/10.33578/prinsip.v2i2.46

jprinsip.ejournal.unri.ac.id

Tabel 4. Hasil Pengamatan Aktivitas Guru pada Siklus I dan Siklus II

\begin{tabular}{|c|c|c|c|}
\hline Siklus & Pertemuan & Persentase & Kategori \\
\hline \multirow[b]{2}{*}{1} & $\mathrm{P} 1$ & $75,25 \%$ & Cukup \\
\hline & $\mathrm{P} 2$ & $80 \%$ & Baik \\
\hline \multicolumn{2}{|c|}{ Rata-Rata Siklus I } & $77,6 \%$ & Cukup \\
\hline \multirow{2}{*}{ II } & $\mathrm{P} 1$ & $95 \%$ & Amat Baik \\
\hline & $\mathrm{P} 2$ & $100 \%$ & Amat Baik \\
\hline \multicolumn{2}{|c|}{ Rata-Rata Siklus II } & $97,5 \%$ & Amat Baik \\
\hline
\end{tabular}

Tabel 4 menunjukkan bahwa rata - rata aktivitas guru dalam proses belajar mengajar setelah penerapan model Discovery Learning terjadi peningkatan. Hal ini terlihat pada siklus I rata-rata $77,6 \%$ dan berada pada kategori cukup, dan pada siklus II, rata - rata aktivitas guru dalam proses belajar mengajar setelah penerapan model Discovery Learning sebesar 97,50\% dan berada pada kategori amat baik. Dengan kata lain rata-rata aktivitas guru dalam proses belajar mengajar setelah penerapan model Discovery Learning dari siklus I ke siklus II mengalami peningkatan. Pada siklus I dengan kategori cukup disebabkan guru tidak menempatkan waktu dengan baik, pengelolaan waktu kurang efisien, terlalu lama anak mengerjakan LAS sehingga waktu kurang sesuai dengan yang direncanakan, serta guru kurang memberi penjelasan tentang hal yang belum dimengerti siswa. Dalam hal ini guru berusaha memperbaiki untuk menyiapkan proses belajar mengajar dengan baik dan sudah mulai mengikuti langkah - langkah yang ada dalam RPP.

Pada siklus II pertemuan 1 dan 2 ratarata aktivitas guru sudah meningkat menjadi $97,50 \%$. Walaupun terjadi peningkatan, guru akan selalu berusaha untuk meningkatkan kinerjanya dalam proses belajar mengajar. Menurut Slameto (2003), peranan dan fungsi guru sangat menentukan serta mempunyai pengaruh yang sangat besar terhadap peningkatan hasil belajar dan mampu mendorong dan memotivasi siswa untuk selalu aktif belajar supaya lebih baik.

Dalam hal tersebut diatas guru berusaha membimbing dan memotivasi siswa, serta menjelaskan kembali materi yang belum dimengerti siswa. Guru yang berhasil menciptakan suasana belajar yang baik akan dapat menyebabkan siswa termotivasi dan aktif dalam belajar, sehingga dapat meningkatkan hasil belajar.

Berdasarkan hasil penelitian maka penelitian tindakan kelas ini dikatakan berhasil. Hal ini dikarenakan telah terjadi peningkatan hasil belajar dan perbaikan proses pembelajaran.

\section{SIMPULAN}

Berdasarkan hasil penelitian dapat disimpulkan bahwa penerapan Model Pembelajaran Discovery Learning dapat meningkatkan hasil belajar Matematika siswa kelas VII A MTs Negeri 2 Bengkalis hal ini dapat dilihat dari:

1. Hasil belajar siswa berdasarkan KKM dari UH I dengan katagori baik (72\%) atau tuntas, dan UH II (92\%) dengan predikat amat baik.

2. Aktivitas belajar siswa dari siklus I ratarata $74 \%$ dengan kategori cukup dan siklus II rata-rata $96 \%$ dengan katagori amat baik

3. Aktivitas guru dari siklus I rata-rata $77,6 \%$ kategori baik dan siklus II rata-rata 97,5\% kategori sangat amat baik.

4. Dengan menerapkan Model Pembelajaran Discovery Learning dapat meningkatkan hasil belajar Matematika siswa kelas VII A semester ganjil MTs Negeri 2 Bengkalis tahun pelajaran 2019/2020.

\section{DAFTAR PUSTAKA}

Arikunto, S. (2011). Prosedur penelitian suatu pendekatan praktek. PT. Rineka Cipta

Budiningsih. (2005) Pengertian model Discovery Learning. Pustaka Mandiri,

Djamarah, S.B. (2006). Strategi belajar mengajar. Rineka Cipta.

Herman, H. (2005). Pengembangan kurikulum dan pembelajaran matematika. Jurusan Pendidikan Matematika Universitas Negeri Malang (UM).

Isrok'atun, \& Amelia R. (2018). Model-model pembelajaran matematika. PT. Bumi Aksara 
Volume 2, Nomor 2, Mei 2020

DOI: https://doi.org/10.33578/prinsip.v2i2.46

jprinsip.ejournal.unri.ac.id

Kusumah W., \& Dwigatama, D. (2008). Mengenal penelitian tindakan kelas. PT. Indeks

Maimunah. (2016). Pengembangan model pembelajaran matematika melalui pemecahan masalah untuk mengembangkan penalaran matematis siswa. Desertasi Universitas Negeri Malang (UM)

Rani, M.T, Armis, \& Maimunah. (2017). Pengembangan perangkat pembelajaran matematika berbasis Discovery Learning pada materi garis dan sudut Kelas VII. Jurnal Online Mahasiswa (JOM) 4(2). 112

Sanjaya, S. (2003). Strategi pembelajaran. . Kencana Primada Media

Slameto. (2003). Belajar dan faktor-faktor yang mempengaruhinya. PT. Rineka Cipta

Subanji (2013). Pembelajaran matematika kreatif dan inovatif. Universitas Negeri Malang UM
Sukayati. (2003). Media pembelajaran. PPPG

Suprayanti, I., Ayub, S., Rahayu, S. (2016). Penerapan model Discovery Learning berbantuan alat peraga sederhana untuk meningkatkan aktivitas dan hasil belajar siswa kelas VII SMPN 5 Jenggot tahun pelajaran 2015/2016. Jurnal Pendidikan Fisika dan Tehnologi, 2(1), 30 - 35. http://dx.doi.org/10.29303/jpft.v2i1.285

Susanti, D., Maimunah, \& Siregar, S.N. (2019) Penerapan model Discovery Learning untuk meningkatkan kemampuan pemahaman matematis peserta didik Kelas XI MIA 1 SMA Babussalam Pekanbaru. Jurnal Online Mahasiswa (JOM). 6(2), 1 - 10

Suyanto. (1997). Pedoman penelitian tindakan kelas. Dikti

Syaiful. (2003). Penelitian hasil belajar. PT Remaja Rosdakarya

Syah. (2004). Psikologi pendidikan dengan pendekatan baru. PT Remaja Rosdakarya 